\title{
Budgettering : een keerpunt
}

Citation for published version (APA):

Groot, L. M. J. (1985). Budgettering : een keerpunt. VAN GORCUM ASSEN/MAASTRICHT. https://doi.org/10.26481/spe.19850301/g

Document status and date:

Published: 01/03/1985

DOI:

$10.26481 / \mathrm{spe} .19850301 \mathrm{lg}$

Document Version:

Publisher's PDF, also known as Version of record

\section{Please check the document version of this publication:}

- A submitted manuscript is the version of the article upon submission and before peer-review. There can be important differences between the submitted version and the official published version of record.

People interested in the research are advised to contact the author for the final version of the publication, or visit the DOI to the publisher's website.

- The final author version and the galley proof are versions of the publication after peer review.

- The final published version features the final layout of the paper including the volume, issue and page numbers.

Link to publication

\footnotetext{
General rights rights.

- You may freely distribute the URL identifying the publication in the public portal. please follow below link for the End User Agreement:

www.umlib.nl/taverne-license

Take down policy

If you believe that this document breaches copyright please contact us at:

repository@maastrichtuniversity.nl

providing details and we will investigate your claim.
}

Copyright and moral rights for the publications made accessible in the public portal are retained by the authors and/or other copyright owners and it is a condition of accessing publications that users recognise and abide by the legal requirements associated with these

- Users may download and print one copy of any publication from the public portal for the purpose of private study or research.

- You may not further distribute the material or use it for any profit-making activity or commercial gain

If the publication is distributed under the terms of Article $25 \mathrm{fa}$ of the Dutch Copyright Act, indicated by the "Taverne" license above, 
WA4

119

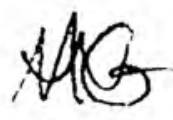

通 Rijksuniversiteit Limburg

Bibliotheek

Postbus $616 \quad 6200$ MD Maastricht

Dit werk terugbezzorgen voor

\begin{tabular}{|c|c|c|}
\hline 28.2 .86 & 12 FEB. 1990 & $30 j u l i ' g 1$ \\
\hline 13.47 & 13 MAART 1990 & 2 JAN. 1992 \\
\hline 27.5 .87 & 9 APR. 1990 & \\
\hline 8 DEC. 1987 & 4 & 17 SEP. 1992 \\
\hline g FEB, 1988 & 29 MEI 1990 & (2) 2 ОKT. 1992 \\
\hline 6 SEP. 1988 & 12 JULI 1990 & Lan \\
\hline $23 \cdots 4988$ & 6 AUG. 1990 & $f 8$ \\
\hline 29 NOV. 1988 & $12 \operatorname{sept} 1990$ & - 5 JAN. 1995 \\
\hline 19 JULI 1989 & 2 JAN. 1991 & T70KT. 1997 \\
\hline 24 OKT. 1989 & $\begin{array}{l}\text { 1 3 FEB, } 1991 \\
\text { 1 \& MAMPI } 1991\end{array}$ & Nôt. 199 \\
\hline 1990 & 24april'q1 & $\begin{array}{l}05 \text { APR. } 2001 \\
14 \text { JUNI 2Qf:- }\end{array}$ \\
\hline
\end{tabular}


BUDGETTERING:

EEN KEERPUNT 


\title{
BUDGETTERING: \\ EEN KEERPUNT
}

\author{
Afscheidscollege \\ uitgesproken ter gelegenheid van \\ zijn emeritaat als hoogleraar \\ Economie van de Gezondheidszorg \\ aan de Rijksuniversiteit Limburg \\ dd. 1 maart 1985 \\ door \\ Prof. Dr. L.M.J. Groot
}

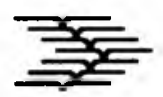




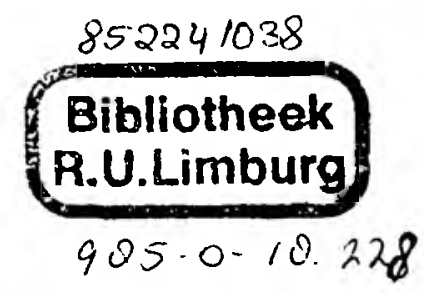

Lay-out en druk: Van Gorcum, Assen 


\title{
Budgettering: Een keerpunt
}

\author{
Afscheidscollege van Prof. Dr. L.M.J. Groot \\ d.d. 1 maart 1985 Rijksuniversiteit Limburg Maastricht
}

\section{Inleiding}

Bij dit afscheidscollege dacht ik goed te doen $U$ een globaal overzicht te geven van het wel en wee van de ziekenhuiseconomie met name gedurende de periode dat ik actief in deze sector bezig ben geweest. Teneinde het betoog te verlevendigen en zoveel mogelijk in de actualiteit te plaatsen zal ik na een korte typering van de economische situatie van het ziekenhuiswezen de budgettering aangrijpen als een welkome gelegenheid om vanuit dit verschijnsel verschillende facetten van ons probleemveld onder de loep te nemen, daarmede zowel verleden, heden alsook de toekomst in deze beschouwingen betrekkend. Mogelijk zullen enkelen onder U zich teleurgesteld voelen, die de gang naar deze jonge Alma Mater hebben afgelegd in de stellige verwachting verwend te worden met een doorwrocht en diepzinnig betoog - als ik dat al zou kunnen - over een slechts door een kleine schaar fijnproevers te vatten onderwerp, waarbij de verslaafden aan dergelijke academische plechtigheden zich kunnen vermeien aan de verwondering over het onbegrepene, dat immers een geheel eigen bekoring kan hebben.

Tegenover de velen echter, die vandaag hier gekomen zijn omwille van mijn afscheid en die het bijwonen van dit college meer beschouwen als een noodzakelijke vertraging in de festiviteiten, die omwille van de universitaire liturgie op een dergelijk afscheid dient te worden geduld, dacht ik goed te doen deze academische vertraging zo prettig mogelijk aan te kleden.

Onze jonge universiteit, die erop gebrand is vermolmde of vermolmd geachte universitaire gebruiken af te schaffen, heeft na een korte periode van het zoveel mogelijk weren van deze gebruiken, geleidelijk aan toch nog gelegenheid gegeven voor het houden van inaugurale en afscheidscolleges. Stap voor stap keert men terug naar de oude gebruiken in de universitaire wereld, getuige ook het wederom invoeren van een cum laude.

Daar ik behoor tot die groep hoogleraren, die in de prille aanvang geleefd hebben in de universitaire woestijn zonder een enkele versiering, heeft dat tot gevolg dat dit afscheidscollege tevens mijn eerste openbare rede voor- 
stelt en aan dit wel zeer unieke en merkwaardig samengaan van inaugurale rede en afscheidscollege meen ik mij het recht te mogen toemeten aan deze gebeurtenis dan ook een bijzondere vorm te geven.

\section{Beginsituatie in 1951}

In 1951 werd ik benoemd tot economisch directeur van het St. Laurentiusziekenhuis te Roermond, dat toendertijd eigendom was en beheerd werd door de Congregatie van de Kleine Zusters van de H. Joseph te Heerlen. Deze congregatie was in 1872 gesticht door Mgr. Petrus Joseph Savelbergh. een figuur die grote betekenis heeft gehad niet alleen voor zijn congregatie maar ook met name voor de volksgezondheid in Limburg. Tijdens zijn leven stichtte de congregatie het ziekenhuis te Heerlen - nu het De Weverziekenhuis - en de zwakzinnigeninrichtingen voor mannelijke en vrouwelijke patiënten te Heel. In de dertiger jaren werd het ziekenhuis te Roermond door de congregatie gesticht, toen deze stond onder leiding van Rector Mgr. Driessen.'

Het ziekenhuis te Roermond was in 1951 nog een van de zeer weinige congregatie-ziekenhuizen in ons land. In afwijking van het beleid, dat dienaangaande door episcopaten in het buitenland gevoerd werd. was het Nederlandse episcopaat de opvatting toegedaan dat dergelijke instituten gezien hun maatschappelijk belang beter door leken dan door congregaties beheerd konden worden en moedigde dan ook de overdracht van dit soort stichtingen aan leken-stichtingen aan. Het zou nog tot 1968 duren voordat het Roermondse ziekenhuis een stichtingsvorm kreeg, nadat in 1963 een adviescollege op bestuurlijk niveau werd geînstalleerd.

Het was dan ook wel een zeer merkwaardig bedrijf waar ik benoemd werd, zonder enige sollicitatie, zonder profielschets en zonder al dat soort zaken die tegenwoordig bij dit soort benoemingen gebruikelijk zijn. Presidentdirecteur was Moeder Overste, mededirecteur was een geneesheer-directeur internist, als raad van commissarissen fungeerde de algemene overste met haar bestuur - enkele representanten ontmoette ik als de problemen daar aanleiding toe gaven - terwijl de Bisschop van Roermond via zijn medewerkers - hierbij moet zeker genoemd worden Mgr. van Odijk, de latere vicaris-generaal - moest inspringen als een Ausputzer van hoge kerkelijke signatuur, als het gebed van de zusters te kort schoot, of als minder geëigend werd beschouwd, hetgeen tot mijn teleurstelling nogal eens het geval bleek te zijn. De organisatie en de gezagsverhoudingen van een dergelijk instituut worden geheel beheerst door de kloosterlijke regels, die resistent bleken te zijn tegen alle pogingen mijnerzijds om de modellen ontleend aan de toendertijd circulerende organisatieliteratuur met veel 
overredingskracht te introduceren. De eerste en enige instructie die ik van de algemene overste mocht meenemen naar Roermond was kort maar krachtig, namelijk: 'Meneer Groot, doet U nu maar wat Moeder U zegt, dan komt alles in orde'. Onder deze zeer eenvoudige en in zijn zeggingskracht zeer pregnante leefregel heb ik overigens - en ik wil dat hier bij deze gelegenheid graag duidelijk verklaren - een uiterst prettige werkkring onder moeders hoede mogen doorbrengen.

De aan het ziekenhuis verbonden specialisten gedroegen zich in die tijd als echte professionele vrijbuiters, overmatig belast zijnde met de patiëntenzorg gezien het gering aantal specialisten dat beschikbaar was. Het spel van deze professionele vrijbuiters met de congregatie maakte op mij altijd de indruk van Japans worstelen. De zusters immer meegaand, immer dienstbaar, altijd voorkomend, maar toch altijd zich zo opstellend, dat de professie hoegenaamd geen greep op de kloostergemeenschap kreeg. Medische stafvorming was zo goed als onbekend. De onderlinge verhoudingen werden beheerst door vriendschappelijke en wandelgangenrelaties, terwijl min of meer onbesuisde initiatieven mijnerzijds de medisch specialisten vaak op een hoop dreven. Op een totaal aantal medewerkers van rond 400 bedroeg het aantal religieuzen ruim 100 . De invloed van de kloostergemeenschap was echter sterker en hechter dan dit aantal zou doen vermoeden, omdat alle strategisch belangrijke posities, met name het middenkader, in handen van de religieuzen lagen.

Ook de economie van dit soort instellingen had geheel eigen trekken. De religieuzen hadden hun eigen honorering, overwegend in natura, en kenden geen vastgestelde werktijden noch vakanties. Deze omstandigheden hadden tot gevolg, dat dit soort ziekenhuizen bijzonder goedkoop kon worden geëxploiteerd. Vooral het feit, dat men niet onderworpen was aan de wettelijke voorschriften met betrekking tot de werktijden leidde er bovendien toe, dat men met veel minder religieuzen kon volstaan dan met leken. Indien een religieus door leken vervangen moest worden, kon men erop rekenen, dat per religieus twee leken nodig waren. Religieuzen liepen - in termen ontleend aan de automobielbranche - één op twee.

Het ziekenhuis beschikte in 1931 over een uitstekende en met veel zorg bijgehouden boekhouding. De boeken werden door de religieuzen in schoonschrift als werkelijk monnikenwerk bijgehouden en bij mijn aanstelling verkeerde aanvankelijk de religieuze comptabele staf in een permanente staat van opwinding uit vrees, dat ikzelf met mijn onbehouwen handschrift deze calligrafische produkten zou ontsieren. Ter geruststelling verzekerde $i k$ hen dat $i k$ in deze richting geheel geen ambities had, een verzekering die ik des te gereder kon afgeven, daar ik mij als een van de eerste taken de mechanisering van de ziekenhuisadministratie gesteld had ${ }^{2}$. 
De boekhouding werd niet alleen uitstekend en met zorg bijgehouden. ook het rekeningstelsel kon de toets van de kritiek zeer wel doorstaan. Men kende de koopmansboekhouding met verantwoording van alle kosten waaronder afschrijvingen, die echter in de eerste jaren niet verdiend konden worden. De congregatie nam namelijk de financiering met alle daaraan verbonden risico's geheel voor haar rekening.

De ziekenhuiswereld in 1951 leefde nog geheel in de schaduw van de Tweede Wereldoorlog. De gevolgen van deze wereldoorlog waren nog scherp merkbaar en drukten hun stempel op het ziekenhuiswezen uit die jaren. Een van de belangrijkste feiten op dit terrein in de Tweede Wereldoorlog was de afkondiging van het Ziekenfondsbesluit van 1941, waarbij de ziekenhuisverstrekking tot het pakket van de verplichte verzekering werd gerekend. Dit besluit kan als een belangrijk breekpunt in de ontwikkeling van het ziekenhuiswezen beschouwd worden, getuige het feit dat de bezettingscijfers van deze instellingen sindsdien enorm gestegen zijn en zodoende aan deze instellingen een betere financiële grondslag werd gegeven dan ooit het geval was geweest.

Een tweede belangrijk facet vormde de verwoesting in de Tweede Wereldoorlog, waarbij het ziekenhuiswezen met andere sectoren in de samenleving een achterstand had opgelopen en zich niet alleen gesteld zag voor een herstelprogramma, maar bovendien ook moest reageren op een sterk stijgende vraag naar haar diensten, nu het sociale zekerheidsstelsel het financieel mogelijk maakte om aan deze behoefte te voldoen.

Tenslotte leefde het ziekenhuiswezen onder het regime van de Prijsopdrijvings- en Hamsterwet van 1939, waarbij het toezicht op de prijsvorming was toevertrouwd aan het Ministerie van Economische Zaken, dat hierdoor toezicht op de exploitaties van deze instellingen ging uitoefenen. Financieel stonden de ziekenhuizen er niet slecht voor. De stijgende bezettingscijfers gecombineerd met maar beperkte mogelijkheden voor aanschaf van goederen leidden tot een behoorlijke mate van liquiditeit.

De invloed van het Ministerie van Economische Zaken op de economische gang van zaken binnen de ziekenhuizen kan moeilijk overschat worden. Het prijzentoezicht leidde ertoe, dat ziekenhuizen die een tariefsverhoging wensten te verkrijgen verplicht waren het verzoek te schragen met een behoorlijke kostenverantwoording. Vele administraties van de ziekenhuizen waren daar echter niet op berekend. Dat gold met name voor de confessionele ziekenhuizen, waar men vergeleken met de overheidsziekenhuizen een behoorlijke achterstand op dit terrein had. De administratie beperkte zich vaak tot een verantwoording van uitsluitend uitgaven en opbrengsten en nog in 1952 meldde de legendarische Wouters van Econo- 
mische Zaken dat men in een confessioneel ziekenhuis de investeringen in één jaar wilde terug verdienen onbekend als de zusters waren met het systeem van afschrijvingen. De confessionele ziekenhuizen hadden in dit opzicht een achterstand omdat men het charitatieve moeilijk met het bedrijfsmatige kon verenigen. Bij de overheidsziekenhuizen lag deze situatie geheel anders. $\mathrm{Zij}$ waren ingebed in de comptabele verantwoordingsplicht aan de overheid en hadden hun comptabiliteit dienovereenkomstig op niveau gehouden. $\mathrm{Zij}$ waren op toezicht van buitenaf reeds goed ingespeeld.

Men vindt dan ook de beoefenaren van de bedrijfseconomie met name in de kringen van de overheidsinstellingen. Op het gevaar af sommigen te vergeten en tekort te doen, wil ik hierbij de namen vermelden van Valk, Könings, Verbeek, de Kievit, als mannen van het allereerste uur en dan Van der Meyden, Van den Boogert, Van der Vegt uit een latere periode. In de confessionele sector waren het met name van Aalst, Tummers, Stalpers en Vinken, die al reeds voor de oorlog met bedrijfseconomische vraagstukken bezig waren. Na de Tweede Wereldoorlog gaat men in confessionele kringen de achterstand inlopen, waarbij de Katholieke Economische Hogeschool de broedplaats bleek te zijn van jonge academisch gevormde economen voor de gezondheidszorg, waaronder ik wil noemen Vissers, Poels, Brüning, De Jong en Verhey en de ons helaas veel te vroeg ontvallen Vermeulen ${ }^{3}$.

Als gevolg van het toezicht van Economische Zaken werd het ziekenhuiswezen op analoge wijze behandeld als het bedrijfsleven. Toetssteen voor de prijzen was daar het gemiddeld redelijk geleide bedrijf en deze filosofie werd ook op het ziekenhuiswezen van toepassing verklaard, een situatie die tot op de dag van heden nog steeds voortduurt ${ }^{4}$. Het gehele kostenbeleid met al zijn richtlijnen stoelt immers op gemiddelden, die op basis van praktijkervaringen worden bepaald. Het prijsbeleid maakte echter twee als smartelijk gevoelde uitzonderingen voor het ziekenhuiswezen namelijk het niet-incalculeren van rente over eigen vermogen en het niet toestaan van een redelijke winstmarge.

De eenmaal in 1939 ingeslagen weg met betrekking tot de kostenbeoordeling en prijsvorming werd gecontinueerd onder de Prijzenwet en kreeg haar eerste regelgeving in de Ziekenhuistariefwet van 1965, die in 1982 werd vervangen door de Wet Tarieven Gezondheidszorg. Voor wat het investeringsbeleid betreft, werd het regime onder de Wederopbouwwet vervangen door een nieuwe regeling op basis van de Wet Ziekenhuisvoorzieningen in 1971 en de wijziging van deze wet in 1977. Aldus waren prijsvorming en investeringen aan eigen wettelijke regelingen onderworpen. 


\section{De budgettering}

In 1983 voert de overheid nog voordat het budgetteringsexperiment met vier ziekenhuizen en één verpleeghuis teneinde was, plotseling een geheel nieuw regime van budgettering voor de algemene en academische ziekenhuizen in, terwijl in 1984 alle andere intramurale instellingen onder dit regime gebracht zijn.

Het belang van de invoering van de budgettering kan naar mijn smaak moeilijk overschat worden. Budgettering zal naar mijn opvatting een zeer grote invloed gaan uitoefenen op allerlei aspecten van de ziekenhuiseconomie en ik wil zulks illustreren door via een soort flash back techniek na te gaan welke implicaties het nieuwe systeem voor een aantal belangrijke aspecten van het ziekenhuiswezen in het bijzonder de ziekenhuiseconomie zal hebben. Dit geeft mij gelegenheid zowel de ontwikkeling van bepaalde aspecten te schetsen alsmede suggesties te doen voor de toekomst. De volgende aspecten zullen de revue passeren:

1. Het rekeningstelsel

2. De kapitaalslasten en de vermogenspositie van het ziekenhuis

3. De inhoud van de ziekenhuiseconomie

4. Verhouding tussen medicus en econoom

5. Economische technieken

6. De regionale budgettering

\section{Het rekeningstelsel}

Zoals reeds vermeld beschikten vele overheidsziekenhuizen over een koopmansboekhouding. Men wilde echter verder gaan dan de eenvoudige boekhouding naar kostensoorten en in 1923 reeds nam de belangrijke Vereniging van Administratieve (Economische) Hoofden van Ziekeninrichtingen het initiatief om een commissie onder leiding van de befaamde Prof. Limperg te belasten met het ontwerpen van een modern rekeningsysteem voor de psychiatrische ziekenhuizen. De commissie verklaarde zich voorstander van het invoeren van een organisch rekeningstelsel, dat met name voor de psychiatrische ziekenhuizen met hun vele bedrijven niet zonder belang geacht moest worden.

In 1934 werd wederom voor deze vereniging, nu de Vereniging voor Administratie en Economie in Ziekeninrichtingen genaamd, een rapport uitgebracht over dit onderwerp maar nu bestemd voor alle algemene ziekenhuizen en ook nu kwam men tot de slotsom dat het van belang was om een organisch rekeningstelsel in de ziekenhuizen in te voeren. 
Veel weerklank had het rapport voor en ook na de Tweede Wereldoorlog overigens niet. Men voelde niet de noodzaak een dergelijk systeem in te voeren, vooral ook omdat het tariefbeleid aansloot bij de kostensoorten. Verder nodigden all-in tarieven niet uit tot het maken van afdelingsrekeningen. Slechts enkele ziekenhuizen gingen er metterdaad toe over dit rekeningsysteem in te voeren. Het Nationaal Ziekenhuisinstituut ontwierp in 1975 een functioneel rekeningstelsel met daarbij behorende computertoepassingen. In 1977 publiceerde het N.Z.I. de eerste statistiek functionele bedrijfsrekening met bedrijfsvergelijkende overzichten ${ }^{5}$. Ook deze functionele bedrijfsrekening vond nog slechts zeer weinig toepassing. Een uitzondering dient gemaakt te worden voor de academische ziekenhuizen, waar deze bedrijfsrekening door het ministerie werd voorgeschreven en sinds 1976 is ingeburgerd.

Met de komst van de budgettering echter is het gedaan met de tot dan toe niet te doorbreken lethargie op dit punt. De interne budgettering kan immers slechts van start gaan, indien niet alleen op het niveau van het totale ziekenhuis maar ook op het niveau van de verschillende afdelingen gegevens beschikbaar komen, die het mogelijk moeten maken zoveel mogelijk medewerkers bij de budgettering te betrekken. Wil het proces van de interne budgettering geen zaak blijven van een vrij machteloze directie, maar inderdaad door de ziekenhuisgemeenschap gedragen worden, dan zal men op zoveel mogelijk verantwoordelijkheden van hoog tot laag een appél moeten kunnen doen. Wil men nog niet overgaan tot een volledig functioneel rekeningstelsel met al zijn doorberekeningen van indirecte kosten, men zal toch in ieder geval zover moeten gaan om enige vorm van responsibility accounting mogelijk te maken hetzij dus via een volledige functionele bedrijfsrekening hetzij via een categorische bedrijfsrekening met verantwoording van de directe kosten naar bepaalde centra, waar de verantwoordelijkheid voor het doen van bestedingen kan worden toegekend.

Nu de budgettering zich niet alleen beperkt tot het ziekenhuis als voorwaarden scheppend milieu voor de medische beroepsuitoefening, maar het medisch handelen zelf tot onderwerp van budgettering maakt, zal het nodig zijn het rekeningsschema verder te verfijnen, zodat gegevens met betrekking tot kosten en produktie kunnen worden verschaft per specialisme en medische functie. Van hieruit openen zich perspectieven voor een patientgerichte verantwoording van produktie en kosten ter ondersteuning van de interne budgettering rond onderzoek en behandeling van patienten.

De in de Verenigde Staten ontwikkelde systemen voor groepering van patienten, zoals bijvoorbeeld het DRG-systeem, de severity of illness index of het staging concept $t^{6}$, waardoor meer zicht gekregen kan worden op de 
verhouding tussen middelen en patientenbehandeling, lijken reële mogelijkheden om op dit stuk verder te komen.

Nederstigt heeft in een onderzoek van het Nationaal Ziekenhuisinstituut in Nederland nagegaan of het nodig is een bijzondere aanpassing van het DRG-stelsel aan Nederlandse verhoudingen te construeren en heeft deze vraag positief menen te moeten beantwoorden met name met betrekking tot de heelkundige specialismen ${ }^{7}$. Momenteel bestaan er plannen om het DRG-systeem in ons land uit te testen voor verschillende doeleinden, waaronder die van de interne budgettering zeker genoemd moet worden. Een boeiend perspectief.

\section{De kapitaalslasten en de vermogenspositie van het ziekenhuis}

Bij de budgettering nemen de kapitaalslasten een zeer bijzondere positie in. Deze zijn namelijk gezien de grondslag waarop afzonderlijk afgeschreven wordt - de aanschafwaarde - zo specifiek voor iedere instelling afzonderlijk, dat zij moeilijk in te passen zijn in algemene budgetformules en daarom ook afzonderlijk moeten worden behandeld zoals ook elders gebeurt bijvoorbeeld in Belgie en Duitsland. Dat ik dit onderwerp in het kader van de budgettering ter sprake breng, is in hoofdzaak te danken aan de omstandigheid dat dit onderwerp de bedrijfseconomische discussies lange tijd beheerst heeft.

Over die afschrijvingen op basis van de aanschafwaarde is veel te doen geweest in het wereldje van de bedrijfseconomen. Het was een van de meest dankbare terreinen waar men de bedrijfseconomische wetenschap meende te kunnen toepassen ${ }^{8}$. De vijftiger jaren worden met name gekenmerkt door het vrijwel onverkort en ongenuanceerd toepassen van allerlei bedrijfseconomische regels, zonder dat men toen nog voldoende oog had voor het eigen karakter van de non-profit instellingen in het algemeen en van het ziekenhuiswezen in het bijzonder.

Naast het streven om de resultaten van de bedrijfseconomie ook voor deze sector te mobiliseren, noopte ook de praktijk van alledag om zich nader over het afschrijvingsprobleem te bezinnen. De sterk stijgende kosten van bouw en inrichting in de naoorlogse periode maakten duidelijk, dat de op de aanschafwaarde berekende afschrijvingen ten enen male onvoldoende zouden zijn om uit eigen middelen de continuïteit van het ziekenhuis in het aanpassingsproces aan veranderende behoeften en mogelijkheden te verzekeren. Een fors beroep op vreemd vermogen was onontkoombaar. De handhaving van het eigen patrimonium deed velen de wens naar voren brengen de afschrijvingen op basis van de vervangingswaarde te calculeren. 
De overheid erkende in eerste instantie deze bezwaren verbonden aan het berekenen van de afschrijving op basis van de aanschafwaarde en gaf in 1949 enig soelaas door toe te staan $f 0.50$ per verpleegdag voor oude ziekenhuizen in te calculeren voor het vormen van een vernieuwingsfonds, dat de waardestijging in de gebouwen zou dienen te compenseren.

Het voornemen om een deel van de bouwkosten te subsidiëren de zgn. onrendabele bouwkosten ter hoogte van $3 / 7$ van de stichtingswaarde teneinde de ziekenhuistarieven meer op het niveau van de consumptieprijsindex te houden, is niet tot uitvoering gebracht. Dat beleid dat wel brede toepassing heeft gevonden in de woningbouw werd niet doorgetrokken naar de gezondheidszorg, zodat men een eigen prijsontwikkeling voor de gezondheidszorg verkreeg.

Volgens velen bracht de afschrijving op basis van de aanschafwaarde het ziekenhuiswezen te zeer in een afhankelijke positie ten opzichte van de kapitaalverschaffers, die bereid moesten zijn om leningen te verschaffen bij het ontbreken van eigen financiering.

Geleidelijk aan zijn de discussies rond dit onderwerp wat verstild. De ervaring immers leerde, dat de continuiteit niet in eerste instantie afhankelijk was van het vermogen om uit eigen middelen investeringen te financieren, maar van de mogelijkheid om de exploitatiekosten te financieren. Crediteuren waren bereid kapitalen te verschaffen in het vooruitzicht dat de afzet van diensten tegen kostendekkende tarieven verzekerd was. Het garantiebeleid van diverse overheden maakte het bovendien mogelijk om tegen aantrekkelijke voorwaarden leningen aan te trekken, waarvan de aflossing gegarandeerd werd door de afschrijvingen op basis van de aanschafwaarde en de rentebetaling door het laten incalculeren van de werkelijk betaalde rente. Zoals de Rabobank in een onlangs verschenen rapport kernachtig formuleert 'de zekerheid voor geld- en kapitaalverschaffing wordt niet gevonden in het vermogen maar in garantie's. Men merkt echter op, dat de zwakke solvabiliteitspositie tegenwoordig echter een probleem gaat worden, nu de garantieverlening door de overheid nadrukkelijk ter discussie staat.

Het calculeren tegen aanschafwaarde had bovendien het voordeel, dat in een tijd van stijgend prijsniveau zich niet teveel liquiditeiten zouden opstapelen bij de ziekenhuizen nog ongeacht de problemen, die verbonden zijn om afschrijvingen op basis van de vervangingswaarde voldoende objectief vast te stellen.

Dergelijke liquiditeitsproblemen behoeven zich niet voor te doen bij die activa, waar sprake kan zijn van een gemiddeld goed gespreide levensduur 
van de onderdelen. In dat geval immers zullen de afschrijvingen op basis van vervangingswaarde nagenoeg op het niveau van de nodige vervangingen kunnen liggen. Het zou een goede zaak zijn. indien men met betrekking tot dié activa, en dat zijn de activa die beheerst worden door de richtlijnen met betrekking tot afschrijvingen en personeel van 1981, calculatie op basis van de vervangingswaarde zou toestaan, zodat ziekenhuizen voor deze activa de financiering uit eigen middelen zouden kunnen verzorgen. Naar mijn opvatting geeft de onlangs in dit jaar ingevoerde richtlijn met betrekking tot investeringen in medische en overige inventarissen nog onvoldoende financieringsmogelijkheid.

Met genoegen en voldoening wil ik verder constateren dat ook de afschrijvingen nu wel bij de budgetformule betrokken zullen worden, zodat binnen het budget een afweging tussen arbeid en kapitaal zal kunnen gaan plaatsvinden.

De discussies op dit terrein hebben zich van de calculaties van afschrijvingen op basis van vervangingswaarde - heeft ook de waardedaling van het onroerend goed niet in zekere mate ontnuchterend gewerkt? - verlegd naar de positie van het eigen vermogen. Een commissie van het Centraal Orgaan Ziekenhuistarieven, ingesteld om zich te buigen over de noodzaak voor het vormen van een eigen vermogen, kwam tot de conclusie, dat het eigen vermogen een nuttige en noodzakelijke functie kon vervullen voor het opvangen van tekorten van beperkte omvang in de exploitatierekening. De commissie adviseerde de mogelijkheid te openen een eigen vermogen te vormen uit de exploitatie tot $5 \%$ van het balanstotaal en de rente hierover bij te schrijven tot een aandeel van $10 \%$ van het balanstotaal ${ }^{10}$.

Bij een aandeel van $10 \%$ van het balanstotaal zou dit aandeel via een inflatiecorrectie in stand gehouden dienen te worden. Het meerdere van deze $10 \%$ zou naar de exploitatierekening geboekt dienen te worden.

De op basis van de conclusies van dit rapport ingediende richtlijnen konden echter de goedkeuring van de overheid niet wegdragen, daar deze andere prioriteiten had met betrekking tot de verruiming van de richtlijnen. Ik dacht bovendien, dat het bijzonder verstandig was van de overheid om richtlijnen in het kader van de vermogenspositie uit de weg te gaan gezien de vele onzekerheden die bij toepassing van dit soort richtlijnen in het spel kunnen komen.

De positie van het eigen vermogen heeft echter in het kader van de budgettering ineens onvermoede aspecten gekregen. Ter stimulering van het streven naar efficiency kunnen onder het budgetteringsregime overschotten worden behouden en komen tekorten voor eigen rekening. Over- 
schotten en tekorten dienen geboekt te worden op de reserverekening aanvaardbare kosten. Deze situatie veronderstelt een reserve voor het opvangen van goede en kwade risico's in de toekomst. Of de reserves, die nu in de eerste jaren uit de overschotten gevormd konden worden - het

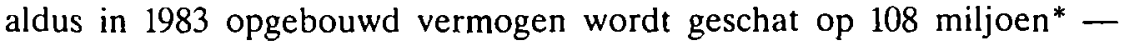
voldoende zullen zijn om risico's op te vangen bij de geplande budgetkortingen in de toekomst valt nog te bezien. In ieder geval heeft de budgettering aan de positie van het eigen vermogen weer een geheel nieuwe dimensie gegeven.

Er is nog een ander aspect aan deze zaak dat enige aandacht verdient. Het verantwoordelijk stellen van instellingen voor overschotten en tekorten wordt gezien als een stimulans voor het bereiken van een redelijke mate van doelmatigheid in de exploitatie. De indruk bestaat, dat de resultaten van deze incentive tot op heden uitsluitend toevallen aan de instelling op zich en nog niet doorwerken naar die onderdelen van de organisatie, die medegewerkt hebben bij het tot stand komen van het voordelig verschil tussen opbrengsten en kosten. Mogelijk ligt voor het localiseren van incentives en het zodoende bevorderen van de doelmatigheid nog een dankbaar probleemveld voor de toekomst. Ik moge hierbij verwijzen naar de interessante experimenten van Wickings"

\section{De inhoud van de ziekenhuiseconomie}

De aandacht van de economen ging aanvankelijk eerst uit naar de economie van de ondersteunende afdelingen in het ziekenhuis. Belangrijke onderwerpen op de agenda waren de efficiency en organisatievraagstukken in grote huishoudens zoals keuken, wasserij en technische dienst ${ }^{12}$. Ook in de inkoop vond men een dankbaar werkterrein, waarbij naast verschillende pogingen om tot een gezamenlijke inkoop te komen, ook genoemd mogen worden vele vruchteloze pogingen om tot normalisatie te komen. De belangstelling voor de inkoop blijkt verder uit een interessant detail, namelijk de criteria die voor ballotage in de Vereniging voor Administratie en Economie werden gehanteerd, namelijk of betrokkene het voor het zeggen had in de inkoop en of hij onmiddellijk toegang tot het bestuur kon krijgen.

In dergelijke ondersteunende afdelingen kunnen bedrijfseconomische overwegingen een gelijke rol spelen als in het bedrijfsleven, terwijl ook oriëntatie op de marktsituatie zeer wel mogelijk is. Een belangrijk vraag-

* Financieel Overzicht Gezondheidszorg en Maatschappelijke Dienstverlening 1985. p. 37. 
stuk, dat op deze wijze benaderd kan worden is de vraag van het al of niet uitbesteden van bepaalde diensten.

Men kan stellen, dat op dit terrein de ziekenhuiseconomie belangrijke successen kon aanwijzen bestaande uit een grotere doelmatigheid waarmee dergelijke diensten werden geëxploiteerd.

Met betrekking tot de hoofdafdelingen, die de patiënt onmiddellijk ten dienste staan, ligt de situatie duidelijk anders. Hier is immers bij gebrek aan een markt geen marktoriëntatie mogelijk, ingekaderd zoals deze hoofdafdelingen zijn in wat wel genoemd wordt de attributie-economie. De taak van de bedrijfseconomie heeft hier bestaan in een zo goed mogelijke kostencalculatie van dergelijke afdelingen meestal met het oog op het vaststellen van tarieven. Ongenoemd mogen hier niet blijven de uitgebreide studies met betrekking tot de laboratoriumtarieven, waar de problematiek geheel eigen trekken ging vertonen door de invoering van automatische analyse apparatuur.

$\mathrm{Bij}$ gebrek aan een mogelijkheid van marktoriëntatie gingen verschillende economen tarieven van dergelijke verrichtingen waarderen als prijzen, d.w.z. als oriënteringspunten voor een economisch verantwoord beleid. De tarieven dienden zodanig vastgesteld te zijn, dat zij voor het economisch doelmatig beleid goede oriëntatiepunten konden bieden. In dit verband noem ik met waardering de namen van Poels ${ }^{13} \mathrm{en}^{\mathrm{k}} \mathrm{de} \mathrm{Jong}^{14}$, die zich met dit vraagstuk zeer intensief hebben beziggehouden. Het vaststellen van dergelijke normtarieven is echter geen eenvoudige zaak mede als gevolg van de beschikbaarheidsfactor van apparatuur in de gezondheidszorg, waarbij het met name moeilijk is om te werken met de normale bezetting van capaciteiten.

Een tweede belangrijk discussiepunt op dit terrein vormde de keuze tussen all-in en all-out tarieven, waar ook talrijke discussies aan gewijd werden.

Met de komst van de budgettering zijn hier twee zeer belangrijke veranderingen opgetreden.

Op de eerste plaats is het tarief als maat voor economisch handelen naar de achtergrond gedrongen, daar het tarief in het nieuwe systeem uitsluitend de functie van financieringsmiddel vervult. Zolang het ziekenhuis met veel debiteuren te maken heeft, zal de financiering altijd via verpleegdagprijzen en tarieven voor bijkomende verrichtingen dienen te verlopen. De budgetten worden echter niet vastgesteld op basis van de kosten van afzonderlijke verrichtingen, maar op basis van de als redelijk beschouwde kosten in hun totaliteit. Het terugdringen van het verrichtingentarief wordt ook wel eens 
verwoord met de overgang van een output- naar een inputfinanciering. Hoewel de output een rol speelt en zal blijven spelen bij het vaststellen van de budgetten ligt de relatie van de output tot de kosten geheel anders bij een financiering op basis van verrichtingen, dan bij een financiering op basis van een overeengekomen budget. Bij de zuivere outputfinanciering is de financiering zelf resultante van het aantal verrichtingen en de prijzen, bij de budgetfinanciering staat de verhouding tussen overeengekomen programma en totale kosten centraal. Het tarief als oriëntatiepunt voor economisch beleid heeft het veld moeten ruimen voor het budget. Deze situatie staat in schrille tegenstelling tot de nieuwe financieringswijze voor een belangrijke groep patiënten - de Medicare patiënten - in de Verenigde Staten, waar men ziekenhuizen wil financieren op basis van prijzen per opneming, de DRG's. De keuze die men daar gemaakt heeft voor de financiering hangt ten nauwste samen met het feit, dat de debiteuren in Amerika geen eenheid vormen, maar door het ziekenhuismanagement zoveel mogelijk tegen elkaar worden uitgespeeld ${ }^{15}$. Een benadering van het instituut als totaliteit is dan natuurlijk niet mogelijk. In New Jersey, waar het DRG-stelsel voor alle patiënten werd ingevoerd, heeft men voorlopig de indruk dat de declaraties gestegen zijn ${ }^{16}$.

Een tweede belangrijke wijziging, die als gevolg van de budgettering optreedt, ligt in de inhoud van de bedrijfseconomische vraagstukken. Vóór de invoering van de budgettering kenden wij in ons land een, zij het op basis van randvoorwaarden, geclausuleerde vrijheid van de medische professie met betrekking tot onderzoek en behandeling van patiënten. De richtlijnen honoreerden de produktie aan verpleegdagen en verrichtingen ongelimiteerd.

In deze context kan de economie zich inhoudelijk beperken tot de doelmatigheid van het programma, zoals dat door de professie wordt voorgeschreven. Met de budgettering zijn de randvoorwaarden stringenter geworden en zijn grenzen gesteld aan de hoeveelheid diensten, die de medische professie kan verstrekken in een bepaalde periode. De doelmatigheid van het programma zelf wordt nu in de beschouwing betrokken. Voor een doelmatigheidsanalyse in deze trant zullen twee belangrijke randvoorwaarden vervuld moeten zijn. Vooreerst dienen de medici gegevens te krijgen waarop zij vanuit hun positie goed kunnen reageren. Dat veronderstelt, zoals reeds vermeld, een specialisme- en patiënt-gerichte administratieve verantwoording en de mogelijkheid om de economische achtergronden van het medisch beleid zichtbaar te maken. Vooral met betrekking tot het zichtbaar maken van de kostenpositie van afdelingen en de verhouding tussen output en input is belangrijk werk verricht onder leiding van Prof. P. Verheijen aan de Katholieke Economische Hogeschool te Tilburg ${ }^{17}$. 
De tweede randvoorwaarde ligt meer bij de medici. Hierbij kan ingespeeld worden op nieuwe inzichten met betrekking tot het begrip kwaliteit, waarin de doelmatigheid mede begrepen is ${ }^{18}$. Het is een boeiend en nog niet opgelost vraagstuk, op welke wijze de arts zijn hulp aan de patiënt doelmatig dient te doseren. Vraagstukken van individuele en collectieve verantwoordelijkheden en belangen spelen hierbij een rol ${ }^{19}$. Ter objectivering van dit moeilijke probleemveld tracht men vanuit de epidemiologie en de medische besliskunde een hanteerbaar denkkader te construeren. In dit verband wil ik graag met waardering melding maken van de werkzaamheden van het $\mathrm{CBO}$, dat vraagstukken van deze aard nader onderzoekt.

Een onderzoek, dat momenteel in onze capaciteitsgroep plaatsvindt met betrekking tot de economische aspecten van de toetsingsarbeid en kwaliteitsbewaking heeft aan het licht gebracht, dat de kwaliteit van de economische paragraaf bij dergelijke toetsingsarbeid geheel afhankelijk is van de kwaliteit van de medische toetsing zelf.

Men zal op dit terrein eenvoudig moeten beginnen om daarmede resultaten van bescheiden formaat te boeken. Overigens behoeft de economie niet alleen volgend te zijn maar kan ook voor de toetsingsarbeid zelf enige oriëntatie bieden. Zo is het denkbaar dat men bij de keuze van toetsingsonderwerpen het economisch gewicht van bepaalde als knelpunten ervaren situaties laat meespelen. Overigens zij nog ten overvloede opgemerkt, dat kwaliteitsbeoordeling aan de hand van resultaten van medisch handelen beslist niet eenvoudiger is geworden bij een verouderende bevolking, waar de resultaten immers vaak moeilijk meetbaar zijn.

Het is hier van belang, dat econoom en medicus geleidelijk aan en samen optrekken. Het forceren van spectaculaire resultaten door voor een economische evaluatie de eis te stellen van uitgewerkte kosten-baten en kosteneffectiviteitsanalyses - waarvan er nog maar weinig zijn - zal ertoe leiden, dat de afstand tussen beiden - econoom en medicus - te groot wordt en dat de medicus geen relatie meer kan zien met het praktische werk waarmee hij bezig is. De handreikingen dienen zodanig te zijn, dat beiden aan het werk kunnen gaan en de huidige beslissingen zo goed mogelijk medisch en economisch kunnen toetsen, hoe onvolmaakt het proces in den aanvang mogelijk ook moge zijn.

De kwaliteitsbewaking zal in het kader van de budgettering steeds belangrijker worden nu grenzen gesteld zijn aan de hoeveelheid en aard van de te leveren diensten. De aldus getrokken grenzen alsmede de verleiding van het ziekenhuis om de produktie te beperken kunnen de kwaliteit van de patiëntenzorg in gevaar brengen.

Daarnaast zullen nieuwe ontwikkelingen het kritisch evalueren van be- 
staande medische arbeid noodzakelijk maken. Geleidelijk aan kom ik dan tot de veranderde functie van de medische professie met betrekking tot het dragen van budgetverantwoordelijkheid.

\section{Verhouding tussen medicus en econoom}

Met de invoering van de budgettering heeft de medicus een nieuwe verantwoordelijkheid en taak binnen het ziekenhuis gekregen, omdat hij binnen dit proces zijn verantwoordelijkheid zal moeten nemen. De intentieverklaring van de Nationale Ziekenhuisraad en de Landelijke Specialistenvereniging beschouw ik als een tussenstation naar de uiteindelijke positie van de specialist binnen het ziekenhuis, waar hij, zoals ook in andere landen geschiedt, budgetverantwoordelijkheid voor zijn specialisme gaat dragen.

Als ik ook hier de methode van de flash-back toepas en nog eens denk aan de verhouding tussen economen en medici binnen de ziekenhuisorganisatie, dan liggen ook hier enorme verschillen. In de vijftiger jaren werd de organisatie van het ziekenhuis geheel gedomineerd door de artsen met in hun kielzog de verplegenden. Het is vermakelijk te lezen in het gedenkboek 'All-in' bij het 50 -jarig bestaan van de Nederlandse Vereniging van Ziekenhuiseconomen hoezeer animositeit heerste tussen medici en economen, zowel op het niveau van het ziekenhuis alsook op het niveau van de verenigingen. De artsen wisten zich bij hun positie gesteund door hun professionele status versterkt nog door een maatschappelijke positie en academische vorming. Hier tegenover was de positie van de self made economen uiterst delicaat en konden de verhoudingen binnen het ziekenhuis volgens Valk beschreven worden als het spel tussen kat en hond, maar meestal had het meer van doen met een kat- en muisspel.

Met de komst van de academisch gevormde economen veranderde hier wel iets. De vooruitzichten als een gesprekspartner van de medici beschouwd te worden, werden enigszins gunstiger. De LSV stuurde mij zelfs een uitnodiging om een voordracht te houden teneinde de leden iets te vertellen over ziekenhuiseconomie. Op de vraag, wat de komst van academisch gevormden zou opleveren met betrekking tot de ontwikkeling van de economie in de ziekenhuizen, antwoordde ik - de grote verdiensten van onze nietacademische collega's indachtig - 'Naar mijn smaak behoeven zij geen beletsel te vormen voor de ontwikkeling van een goede ziekenhuiseconomie'.

In het begin van de vijftiger jaren zag men de parttime directeur-specialist het veld ruimen voor de fulltime directeur-geneesheer, gerecruteerd uit specialisten, huisartsen en sociaal geneeskundigen. Men dacht door het aanstellen van dergelijke volambtelijke geneeskundigen het medisch be- 
leid sterker verankerd te hebben als gevolg van meer beschikbare tijd en het wegruimen van belangenconflicten. Ik heb echter mijn sterke twijfels of deze verandering met betrekking tot de strikt medische component wel als een succes kan worden beschouwd. Afgezien van het feit, dat hierdoor mogelijk aan patiëntenbelangen meer aandacht gegeven kon worden - en dan hebben wij te maken met een context die breder ligt dan de strikt medische - heb ik toch de indruk, dat met het verdwijnen van de geneesheer-directeur de directe voeling met het medische werk voor het management niet versterkt is. Het is niet onmogelijk, dat het directiebeleid inboette aan directe contactmogelijkheden met het medische werk. een ontwikkeling, waardoor de medische component zich meer autonoom kon uitkristalliseren, vooral nu in die tijd de medische stafvorming op gang begon te komen.

De verhoudingen tussen de medische en economische component op het niveau van het management krijgen bij deze volambtelijke status van de medicus wel eigen kenmerken. Men kon gezien de gelijke ambtelijke status meer op gelijk niveau gaan werken en ik wil niet uitsluiten, dat hierdoor de positie van de econoom binnen de organisatie zelf is versterkt.

Overigens kan men nu waarnemen, dat men geleerd heeft management als een geheel eigen deskundigheid te zien los van disciplines zoals de medische en economische wetenschappen. Het bestaan van de Nederlandse Vereniging van Ziekenhuisdirecteuren naast een Nederlandse Vereniging voor Ziekenhuiseconomen geeft hieraan duidelijk gestalte.

Met de budgettering zal dus de verantwoordelijkheid van de professie zich ook gaan uitbreiden tot de totstandkoming en bewaking van een budget ${ }^{20}$. Die verantwoordelijkheid kan waargemaakt worden naar mate het informatiesysteem adequater is. Boerma heeft erop gewezen, hoe de verfijning van de administratie via de DRG's het management in staat stelt zich wat meer afstandelijk op te stellen tegenover het beleid van de medische professie ${ }^{16.21}$. Het beleid kan zodoende inderdaad gedecentraliseerd worden en meer verantwoordelijkheid kan dan toevallen aan de artsen-afdelingshoofden. Een goede kwaliteit van ziekenhuiszorg is immers alleen mogelijk, indien de specialisten hun verantwoordelijkheid nemen en dienovereenkomstig handelen.

Specialisten zullen meer tijd moeten geven aan niet-patiënt gebonden werkzaamheden en zich moeten inwerken in de problematiek, die hiermee verbonden is. Dat deze ontwikkeling meer specialisten zal vragen behoeft geen betoog. Meer normale werktijden met daarnaast een groter aandeel van niet patiëntgebonden werkzaamheden zullen een belangrijke factor kunnen zijn bij het terugdringen van de werkloosheid onder artsen. 
De combinatie van niet gebudgetteerde specialisten en wel gebudgetteerde instellingen roept mogelijk knelpunten op, waarvan de een de creatieve mogelijkheden zal roemen en de andere de splijtzwam binnen de organisatie zal duchten. Elders heb ik erop gewezen, dat het dienstverband voor specialisten in de toekomst een aanvaardbaar en reëel alternatief voor de honorering kan zijn*. Het vaststellen van norminkomens, het kaderen van de post specialistische hulp binnen het FOGM en de combinatie met het ziekenhuisbudget zullen zeker katalyserend werken in dit opzicht. Goede arbeidsovereenkomsten in combinatie met een degelijk professioneel statuut, waar de patienten-belangen gewaarborgd worden, lijken mij perspectieven te bieden. Goedkoper zal het niet worden, want medici zullen alleen genegen zijn een dienstverband te aanvaarden als dit voor henzelf en voor de groep geen achteruitgang betekent. In mijn herinnering bewaar ik nog onuitwisbaar de strijdkreet van de knappe onderhandelaar Dubois, oogarts, voor de LSV 'Groot, nooit tornen aan verkregen onrechten'.

\section{De economische technieken}

Bij mijn terugblik op het verleden vanuit het heden wil ik ook even de schijnwerper plaatsen op de technieken, die in de ziekenhuiseconomie werden en worden toegepast. In het kader van het prijsbeleid zich oriënterend op het gemiddeld goed geleide bedrijf mag het geen verwondering wekken, dat de techniek van de bedrijfsvergelijking zowel onderling als in de tijd in belangrijke mate toepassing heeft gevonden. Met name het Nationaal Ziekenhuisinstituut heeft hier zeer veel en goed werk verricht in het belang van de bedrijfstak en in het belang van de afzonderlijke ziekenhuizen, die hun eigen situatie konden vergelijken met andere ziekenhuizen. De ontwikkeling van het richtlijnensysteem is in belangrijke mate afhankelijk geweest van goede bedrijfsvergelijkingen.

Naast deze eenvoudige technieken komen voor en na meer geavanceerde technieken aan bod. De technieken bekend onder de term operations research zijn met name toegepast binnen de Technische Hogeschool te Eindhoven onder leiding van Prof. Monhemius, waar talrijke interessante studies met betrekking tot de organisatie en personeelsinzet in het algemeen ziekenhuis verschenen zijn ${ }^{22}$.

Een meer geavanceerde techniek vindt men onder meer bij de bedrijfseconometrie. Deze econometrische technieken hebben belangrijke toepassing gevonden bij het verklaren van de kostenverschillen, de kostenstructuur, de relatie tussen omvang en kosten en de invloed van de verschillende

\footnotetext{
* Zie literatuur.
} 
variabelen op kosten en ook op de personeelsbezetting. Dergelijke studies hebben hun neerslag gevonden in het Basisonderzoek Kostenstructuur Ziekenhuizen en Verpleeghuizen ${ }^{23}$. Van Montfort ontwikkelde in het kader van dit onderzoek produktiefuncties voor ziekenhuizen ${ }^{24}$. De onmiddellijke implicaties van deze studies voor het praktische beleid zijn niet eenvoudig te peilen. Het onderzoek lijdt onder de handicap, dat de gebruikte technieken niet voor iedereen direct inzichtelijk zijn en zulks vormt een beletsel om de resultaten van het onderzoek direct met beleid in verband te brengen. Het is niet onmogelijk, dat de nieuwe generatie, beter voorzien van wiskundige bagage, gewend aan computers in het bedrijf en thuis, met deze technieken meer vertrouwd is en er mee om kan gaan. Hierdoor zullen deze technieken ook in het praktische beleid aangewend worden. Het econometrisch onderzoek is zeker niet zonder resultaat gebleven. Op de eerste plaats is er een behoorlijk databestand gekomen voor de ziekenhuizen en heeft men op basis van functionele kenmerken een nieuwe groepering van ziekenhuizen gevonden, die geleidelijk aan meer ingang gaat vinden. Verder is het beleid met betrekking tot deze sector mogelijk beinvloed door de algemene noties rond de kostenstructuur die het onderzoek heeft opgeleverd. Het inzicht, dat de kosten van dergelijke instellingen op korte termijn vrij constant zijn, heeft mogelijk ook een rol gespeeld bij de invoering van de budgettering.

Met de komst van de budgettering zoekt men naar een goed instrumentarium om de budgetten van ziekenhuizen vast te stellen en ook hier zullen deze econometrische technieken een rol spelen. Op de eerste plaats zie ik een mogelijkheid om de vast-variabele techniek, die in de heden toegepaste Bredero-formule een belangrijke rol speelt, met uitkomsten van econometrische studies nader te onderbouwen. De gedachte om de budgetten van ziekenhuizen vast te stellen op basis van de volgens het econometrisch model voor dat ziekenhuis te verwachten kosten, blijkt wegens het schattingskarakter van de modellen en de belangrijke financiële gevolgen van de budgetvaststelling voor het ziekenhuis niet voor verwezenlijking vatbaar.

De econometrische modellen kunnen wel goede diensten bewijzen bij het groeperen van ziekenhuizen op basis van bepaalde kenmerken, indien men de methode van het referentieziekenhuis, zoals deze in Quebec in Canada en mogelijk in de toekomst in België wordt toegepast, gaat invoeren. De econometrische modellen zelf kunnen dan bij deze vergelijking van het ziekenhuis met zijn referentieziekenhuis een zekere verfijning bij de budgetvaststelling brengen. Onderzoek van het cijfermateriaal leert dan welke variabelen voor de groepering van ziekenhuizen van belang kunnen zijn. Er zijn reeds verscheidene pogingen gedaan en het blijkt, dat men met eenvoudige variabelen een heel eind komt. Naast een model waarin opgenomen waren de samenstelling van de medische staf, faciliteiten, aantal 
specialisten en het aantal beschikbare bedden ${ }^{25}$ is nu een model ontwikkeld waarin het aandeel van de interne vakken, het aandeel van de chirurgische vakken, het aantal specialisten, beschikbaar aantal bedden en het percentage inwoners boven de 65 jaar de variabelene zijn ${ }^{26}$.

Het ligt in de bedoeling die variabelen zo veel mogelijk te laten aansluiten aan planningskenmerken om op deze wijze een functionele budgettering mogelijk te maken. Dit brengt mij op de volgende suggestie. Nagegaan dient te worden, of en in hoeverre planningskenmerken en de artikel 18 voorzieningen zich duidelijk uit het cijfermateriaal kunnen profileren bij het zoeken naar het goede referentieziekenhuis.

Voorzover planningskenmerken en ook artikel 18 voorzieningen zich als zodanig niet als kenmerkend onderscheid kunnen laten gelden, lijkt het mij aan te bevelen om deze variabelen uit het planningscircuit te elimineren. Momenteel bestaat al te zeer de neiging om iedere nieuwigheid zonder meer tot apart planningskenmerk te gaan rekenen. Met erkenning dat bij invoering van dergelijke voorzieningen een zekere wettelijke begeleiding nodig kan zijn, lijkt het mij toch het overwegen waard om uit kostenoverwegingen sommige voorzieningen na enige tijd te schrappen, daarbij de vrijheid latend voor de introduktie van dergelijke voorzieningen in het normale proces van budgettering. Een al te gedetailleerde toepassing van artikel 18 en een systeem van zeer gedifferentieerde planningskenmerken kunnen moeilijk in overeenstemming gebracht worden met een klimaat van budgettering met zijn vrijheid van besteding en herallocatie.

Een nieuwe toepassing van de econometrie staat voor de deur, namelijk in het openleggen van de verhouding van output en input op afdelingen van het ziekenhuis en het binnenkort te verschijnen proefschrift van Nederstigt* zal hieromtrent indicaties kunnen geven.

\section{De regionale budgettering}

Een geheel nieuwe ontwikkeling op het terrein van de instellingseconomie wordt ingeleid met het tijdperk van de regionale budgettering en de regionale financiële kaders. Ook hier laat een flash back merkwaardige ontwikkelingen zien. Vroeger leefden de ziekenhuizen met elkaar vaak in felle competitie om zoveel mogelijk voorzieningen binnen te halen. Samenwerking in Nederland is nimmer eenvoudig geweest zoals het proefschrift van Können ${ }^{27}$ heeft laten zien. Kennelijk slagen wij er niet in om zoals de

* Zie literatuur. 
Amerikanen ketens van ziekenhuizen in het leven te roepen, die het zeer goed doen in de gezondheidszorg.

Nu echter de overheid in de Wet Voorzieningen Gezondheidszorg besloten heeft tot decentralisatie van bestuur en de (sub)regionale gezondheidszorg hoog in het vaandel heeft staan, zullen de (sub) regionale financiële kaders en daarop inspelende (sub)regionale begrotingen een belangrijke rol gaan spelen $^{28}$. Voor het tot stand brengen van een goed (sub)regionaal beleid kan de (sub)regionale begroting met zijn begrotingen van verschillende sectoren, tesamen met de circuitbegrotingen een belangrijk hulpmiddel zijn om het beleid van de verschillende instellingen van gezondheidszorg en de vrije beroepsbeoefenaren zodanig op elkaar af te stemmen, dat een (sub)regionale gezondheidszorg gaat ontstaan, die inspeelt op de behoeften van de bevolking in de (sub)regio en anderzijds herkenbaar is in het nationale beleid.

(Sub)regionale begrotingen en financiële kaders zijn echter slechts hulpmiddelen. Essentieel is het ontstaan van een (sub)regionaal management in de gezondheidszorg, dat tot heden nog maar weinig uit de verf gekomen is. In de toekomst zal de aandacht in belangrijke mate uitgaan naar het delicate samenspel van overheid, financiers en instellingen teneinde het regionaal beleid gestalte te kunnen geven.

Hier ligt een belangrijk aandachtsveld voor onze universiteit in de toekomst.

\section{Afsluiting}

Hier eindigt dan mijn rondgang op het terrein van de ziekenhuiseconomie gedurende de periode 1951 tot heden. Er is heel wat veranderd in het ziekenhuis van Moeder Overste in 1951. Er hebben zich grote veranderingen zowel intern als extern voltrokken en de bedrijfseconomische vraagstukken hebben zich verdiept zowel binnen het ziekenhuis alsook in relatie met de omgeving. Dat ik hierbij de budgettering als een bijzonder belangrijk katalyserend element beschouw, is $U$ wel duidelijk geworden. Naar mijn opvatting is de budgettering een van de belangrijkste ontwikkelingen in dit vakgebied, zij heeft perspectieven geopend, die in het verleden hooguit als fata morgana bestempeld konden worden.

$U$ ziet dan ook voor $U$ iemand die vol dankbaarheid is dat hij deze ontwikkeling heeft mogen meemaken en veel van zijn idealen heeft zien omzetten in de realiteit. 
Die dankbaarheid wordt ook gevoed door de bijzonder waardevolle persoonlijke contacten en de daardoor ontstane goede relaties. Een mens leeft niet voor zich zelf alleen en wat hij is wordt mede door anderen bepaald. Vooreerst door zijn opvoeders, zijn ouders en leermeesters met als centrale figuur zijn onvergetelijke promotor Prof. Dr. P.P. van Berkum van de Katholieke Hogeschool te Tilburg, die een belangrijk aandeel heeft gehad in de ontwikkeling en stimulering van dit vakgebied. Velen hebben mij geholpen tijdens mijn werkzaamheden voor de gezondheidszorg. Als ik hier nu enkele organisaties wil noemen, dan zijn hiermede ook gememoreerd de medewerkers van hoog tot laag, die ik in het kader van deze instellingen heb mogen ontmoeten. Ik wil dan gaarne noemen de Congregatie van de Kleine Zusters van de H. Joseph te Heerlen, het St. Laurentiusziekenhuis, de Katholieke Universiteit te Leuven, dèze universiteit en niet in het minst het Ministerie van Welzijn, Volksgezondheid en Cultuur, waar ik sedert 1980 werkzaam ben als extern adviseur van de DirecteurGeneraal van de Volksgezondheid. Daarnaast moet ik zeker noemen de zeer prettige contacten met de organisaties zoals de NZR, het NZI, de KNMG, waaronder speciaal de LSV, de VNZ, de KLOZ, het COZ later COTG, het CBS en het College voor Ziekenhuisvoorzieningen. Voor wat Limburg betreft wil ik graag noemen de provinciale overheid, de Provinciale Raad voor de Volksgezondheid, de samenwerkingsverbanden MRC, SGML en SGNL, instanties en organen, die zo bereidwillig hebben meegewerkt bij het project Regionale Begroting. U allen ben ik bijzonder dankbaar en het is passend op deze dag hieraan uitdrukking te geven.

In de nauwere persoonlijke kring denk ik aan collega Frans Rutten, die zich zo sympathiek heeft opgesteld en aan wie ik de boedel gaarne overlaat.

Bijzonder veel dank ben ik verschuldigd aan Nel van den Beucken voor haar jarenlange trouw en toewijding.

$\mathrm{Bij}$ het beëindigen van mijn werkzaamheden aan deze universiteit past het mij deze universiteit het beste voor de toekomst te wensen. In de afgelopen periode heeft de universiteit, geplaatst als zij was in een periode van opbouw, heel wat inspanningen moeten doen om die voorzieningen te veroveren, die zij onontbeerlijk achtte voor haar ontplooiing vooral met betrekking tot de medische faculteit. Ik hoop, dat in de toekomst de Medische Faculteit en de Algemene Faculteit Studierichting, Gezondheidswetenschappen het als een zeer bijzondere taak zullen blijven zien om in de toekomstige gezondheidszorg de ideale verhouding tussen doeleinden en middelen tot stand te brengen. Uit dit afscheidscollege moge het $U$ duidelijk zijn, dat de budgettering - dit belangrijke keerpunt in de gezondheidszorg - belangrijke perspectieven gaat openen voor de integratie van geneeskunde en economie. Ik hoop dan ook van harte, dat Maastricht erin zal slagen deze integratie in het bijzonder binnen de Medische Faculteit in 
onderzoek en opleiding tot stand te brengen, waarlijk een opgave van allure.

Ik dank U voor Uw aandacht.

\section{Literatuur}

1. Levenslicht van een Honderdjarige. Heerlen 1972.

2. Tot heil der Zieken. Gedenkboek St. Laurentiusziekenhuis. Roermond. 1981

3. All in Van Charitas tot recht op gezondheidszorg. Uitgave ter gelegenheid van het 50 jarig bestaan van de Nederlandse Vereniging van Ziekenhuiseconomen.

4. Groot, L.M.J. Prijsvorming van ziekenhuisdiensten. Proefschrift Roermond. 1960.

5. $\quad$ N.Z.I. Statistick Functionele Bedrijfsrekening 1977.

6. Office of Technology Assessment. Diagnosis Related Groups and the Medicare program: implications for medical technology - technical memorandum. Congress of the United States, nr. OTA-TH-M-17. Washington. July 1983.

7. Nederstigt, P.F.P.M. Diagnosis Related Groups. NZI 84.391.

8. Groot, L.M.J. De actualiteit van afschrijvingstheoriëen voor het ziekenhuiswezen. Acta Hospitalia, Vol. III, ns. 4. december 1963. 295-381.

9. Rabobank. Bedrijfstakstudie Intramurale Gezondheidszorg, p. 16.

10. Straaten, H.C. van. Eigen vermogen in de gezondheidszorg, vervangingswaarde, rente over eigen vermogen verliesfinanciering. Prijs voor Gezondheid, 1984, 113-124.

11. Wickings, H.J. Experiments with clinical budgeting in the British NHS. Ziekenhuis en Budget, Guus Schrijvers (ed), 171-200.

12. Groot, L.M.J. Situatic en Perspectief van de Ziekenhuiseconomic. Economische Essays, 1971, 27-48.

13. Poels, A. De invloed van de financiering op de beoefening van de gezondheidszorg. Het Ziekenhuis, (1973) 3, nr. 6, pag. 341 e.v.

14. Jong, L.P. de. Ziekenhuiskosten en Ziekenhuistarief, Proefschrift, Agon Elscvicr, 1967. Jong, L.P. de. De functic van het ziekenhuistarief. Het Ziekenhuis (1973) 3. nr. 8, pag. 424 e.v.

15. Glaser, William A. Juggling Multiple Payers: American problems and Foreign Solutions. Inquiry Summer 1984, Volume 21, 178-188.

16. May Joel J. and Jeffrey Wasserman. Selected results from an Evaluation of the New Jersey Diagnosis Related Group System. Health Services Research, vol. 19, nr. 5 , December 1984, 547-559.

16a. Groot. L.M.J. Perspectieven voor het vrije beroep. Vrij ondernemerschap of dienstverband? In: Medisch Contact nr. 13, 1985, p. 379.

17. Hilst, J. v.d., J.J.G. Jongen, E.A.M. Koopmans. A.L.J.M. Luyk, Een Ziekenhuiskostenmodel. Instituut voor Gezondheidszorg, Katholieke Economische Hogeschool, Tilburg. Leiten, J.S. De kostprijs van een chemische analyse. Symposiumverslag van het 2 daags symposium 'Kostenbeheersing in de klinische chemie' 17 en 18 november 1983. Nederlands Congresgebouw Den Haag.

18. Vuori, Hannu V. Quality Assurance of Health Services. Regional Office for Europe. WHO Copenhagen, 1982.

19. Mechanic, D. Sounding Board Public Perceptions of Medicine. The New England Journal of Medicine, 312 (1985), nr. 3, 181-183.

20. Heyssel, Robert M. e.a. Decentralized Management in a tcaching hospital. The New England Journal of Medicine, vol. 310, nr. 22, 1477-1480.

21. Boerma, Hans. The organizational impact of DRG's health insurance and educational trust of New Jersey at the Center of Health Affairs, Princeton.

22. Vries, G. de. Evenwicht in zorgvraag en zorgaanbod; bestudering van de afstemming op verpleegafdeling. Proefschrift Technische Hogeschool Eindhoven. 
23. Aert, van J.H. Ziekenhuiskosten in Economisch Perspectief 1977. Proefschrift NZI.

24. Montfort, van A.P.W.P. Production Functions for general hospitals 1980, Proefschrift NZI.

25. Interim Rapport Experimenten Budgettering Ziekenhuizen NZI 83.352.

26. Interimrapportage 'Regionaal Overleg Budgettering Leiden' NZI.

26a. Nederstigt, P.F.P.M. Diagnosis Related Groups. Een patiënt-georiënteerd kosteninformatiesysteem. Proefschrift NZI.

27. Können, E.E. Samenwerking, Fusie en Regionalisatie. Proefschrift.

28. Freens, R.J.M., L.M.J. Groot, F.G.H. Tijhuis. Regionale Begroting Gezondheidszorg; een verkennend onderzoek in Zuid-Limburg. 